\title{
ENTRANTS TO TEACHER EDUCATION COURSES
}

One reason given for the unsatisfactory quality of teacher education is the unsatisfactory calibre of those admitted to courses; in 'Teacher Education in Ceylon' (67), for example, K. Nesiah emphasizes the point - "a problem is the defective quality of the bulk of entrants to both levels of training colleges". Clearly major factors are the motivation and the calibre of those who seek admission to colleges of education, for unless suitably qualified students come forward for the right sort of reasons the quality of teacher education, and hence that of education generally, is imperilled.

In country after country the low status of the teaching profession is seen as having a detrimental effect upon the recruitment of suitable students for colleges of education. The general background in respect of Africa is examined in S.H.M. Jones' Field Report on the Survey of the Status of the Teaching Profession in Africa (117) which was carried out on behalf of the World Confederation of Organisations of the Teaching Profession. R.J. Smyke in Problems of Teacher Supply and Demand in Africa South of the Sahara (89) sees the crux of the problem thus: "to recruit, select and train the best candidates, and to retain teachers in the profession, requires of society recognition of teachers' status, and of teachers, recognition of their professional responsibilities". From Singapore, the Research Unit of the Teachers Training College reports its findings in Why Teach? A Study of Motives for Choosing Teaching as a Career (157): "teaching posts should be filled only by candidates who have a favourable attitude towards teaching as a career, and not by those who regard teaching merely as another occupation". In 'Teachers and Teaching in Nigeria - A Subjective Viewpoint' (68), Uga Onwuka concentrates attention upon a widespread impression of the low status of teachers in society and of teaching being "a last resort". This impression he attributes not only to inferior salaries and conditions of work and to the dilution of the profession by the untrained but also to teachers neglecting their professional responsibilities. He reiterates the point that "the general impressions about teachers and teaching influence the type of recruits into the teaching profession". In India, reports S. Shukla in 'Education and Training of Teachers in India' (86), "the level of ability recruited would be very low indeed were it not for the fact that there is considerable unemployment amongst secondary school leavers". And other writers and conference reports reiterate the theme.

Others prefer to stress the beneficial effects upon teacher education which would result from improving the terms of service and the professional 'image' of teachers. This was the approach of the XXVIth International conference on Public Education. Geneva. 1963 (121) organized by UNESCO; of the Report of the First National Seminar on The Education of Primary Teachers in India (119) which recommended not only rates of pay commensurate with those of other jobs requiring the same qualifications but also such inducements as free education for teachers' children, free accommodation and free medicine; of John Osogo in 'Pepping Up Kenya's Teaching Profession' (69); and, in the West Indies, of the delegation from Montserrat as reported in the Report of Conference on Teacher Education (St. Vincent, 1967) (155).

This positive approach is summed up by the working party on 'Status and Conditions of Service of Teachers' in the Report of the Sixth Annual Conference of the Afro-Anglo-American Programme (132). 
However, it is also very evident that improving the status of the teaching profession is not regarded as the sole solution to the problems of ensuring that the best possible candidates are admitted to colleges of education. Attention is also being directed to methods of selection. In 'Selection Procedures for Teacher Training Colleges' (73) A.S. Phillips reports on investigations in Africa into various methods of selection to colleges of education: pre-college teaching; intelligence testing; academic success; personality assessment; and the interview. A. Gradusson in 'Problems of Teacher Training in Jamaica' (36) describes admission to colleges as "a jumbled arrangement; between the best and the worst there is a wide margin in ability, skill and inclination", and advocates the use of some form of aptitude test, while vocational guidance is recommended by the Research Unit of the Teachers Training College, Singapore (157). E. A. Pires in Primary Teaching Training in Asia (76) expresses concern about faulty selection and suggests possible improvements; and so does S.P. Lo in 'Teacher Training in Sabah' (58).

Thus both an improvement in the status of the teaching profession and an improvement in the methods of selection to colleges of education are regarded as major factors in improving the quality of teacher education. The latter may well prove the more feasible. 